\title{
Effectiveness of Multi-Cycle DEAL Teaching Model To Improve The Science Concept of Elementary School Students
}

\author{
Suryanti ${ }^{1} *$ \\ ${ }^{1}$ State University of Surabaya, Ketintang Street, Surabaya 60231, Indonesia \\ *Correspondign author: Tel: 62-31-878-0009, E-mail: suryantiunesa@gmail.com
}

Received: October 30, 2013 Accepted: December 10, 2013 Published: December 21, 2013

doi:10.5296/ije.v5i4.4811ＵRL: http://dx.doi.org/10.5296/ije.v5i4.4811

\begin{abstract}
This study aims to determine the effectiveness of Multi-Cycle DEAL teaching model to improve elementary students' mastery of science concepts. The subject of this study was fourth grade elementary school students in Surabaya. The research was conducted in the second semester of the school year 2012/2012 by using Randomized Control Group Pretest-Posttest Design. The research data were collected with mastery test of science concepts. Research data were analyzed using ANOVA. Results showed that learning science by using the Multi Cycle DEAL teaching model is more effective to improve the mastery of science concepts to elementary school students learning compared to the previous teaching models. Based on these results, further research needs to be done with a range of material and the broader subject of research.
\end{abstract}

Keywords: learning models; Multi Cycle DEAL; mastery of concepts; science teaching in elementary schools 


\section{Introduction}

Based on Permendiknas Number 22 Year 2006 about Content Standard, the objectives of Science subject in elementary school are (a) developing knowledge and understanding on Science concepts that are beneficial and applicable in daily life and (b) using process skills to investigate surrounding environment, to solve problems, and to make decision. Hence, students are required to master concepts by using process skills, and the concepts obtained are used to solve problems and to make decision in their daily life.

As a matter of fact, elementary schools' students recent result of science learning which is in the form of concepts mastery is still low (Sadia, 2003). Their ability to make decision is also still low. It is in line with the research of Suryanti (2012) which found that elementary school students have not mastered decision making skill.

Based on the objectives of science subject in elementary schools, concepts mastery and ability to make decision should be carried out integratedly in classroom teaching of science. Unfortunately, the condition of Science teaching in elementary schools has not met the objective yet. It is found in a research conducted by Suryanti (2012) that generally teachers do not or have not trained their students decision making skill to integratedly in their lesson. It indicates that skill in making decision has not become the objective of Science in elementary school. It is in line with Campbell et al., (1997: 2) that traditionally skill in making decision has not been included integratedly in the teaching of Science in elementary school. Therefore, some efforts need to be done to make the skill in making decision become an integrated part of Science in elementary school by providing learning environments which support to train decision making skill and to teach Science concepts mastery for students to solve problems. Thus, a method which is suitable with Science concepts mastery and skill in making decision needs to be taught intedratedly in Science teaching and learning.

One way that can be applied is developing Multy-Cycle DEAL Teaching Model. This model is carried out with the following stages: Discussion, Exploration, Analysis, and Look-back, in which in each stage there is a guide to train decision making skill by using DEAL stages. This Multy-Cycle DEAL Teaching Model has been validated by experts and tried out limitedly to know the use of the model in classrooms. To find out how Multy-Cycle DEAL Teaching Model is carried out in larger scales, a further study needs to be conducted.

Based on the explanation above, the general purpose of this research is to know the effectiveness of Multy-Cycle DEAL Teaching Model to improve elementary school students Science concepts mastery. The specific objectives of this research are 1) to find out how elementary school students science concepts mastery is; 2) to reveal whether there are differences in the science concepts mastery between those of the students who are taught with Multy-Cycle DEAL Teaching Model and the ones who are taught with the model which is previously used; 3) to find out whether there are differences in the concept mastery of the students from different school accreditation status; and 4) to find out whether there is interaction between the kinds of the teaching model and the school accreditation status towards elementary school students' science concepts mastery. The material used in this research is Science material for fourth graders in semester 1 and 2 i.e. on a) SK 6 about 
understanding objects characteristics and shape changes as well as how to use an object based on its characteristics; and b) SK 7 about understanding that force can change the state of motion and/or the shape of an object.

\section{Method}

This is an experimental research with Randomized Pretest-Posttest Control Group Design (Fraenkel \& Wallen, 2003: 274). In this design, a group of students from the schools which are the population of this research are chosen randomly to be classified into two groups i.e. control group and experimental group. Both groups are tested to find out the students' initial ability on Science concepts mastery. Then, the experimental group is taught with Science by using Multy-Cycle DEAL Teaching Model whereas the control group is taught by using the teaching model which is usually used by classroom teachers. In the end of the program, both groups are tested in a posttest on concept mastery.

The population of this research is all elementary school students in Surabaya who are spread in 534 elementary schools. The sample is selected with stratified purposive random sampling to test the validation of the model (experimental research). Based on the criteria, 554 sample students are selected from 16 elementary schools with A, B, and C school accreditation status. The number of the sample for the control group is 264 students and for the experimental group is 290 students. The instrument which is used in this research is a test on Science concepts mastery. Generally, the data analysis technique used in this research is descriptive and inferential analysis. Descriptive analysis is used for the information which is based on particular category and in the form of quantitative i.e. in the form of percentage, the average, and the standard deviation of the data. Inferential analysis is used to find out the effectiveness of the teaching model by conducting two-ways analysis of variance (ANOVA) with equal cell.

\section{Research Findings and Discussion}

The test instrument id used to measure elementary schools students' Science concepts mastery. The concepts mastery data of the pretest, posttest, and N-gain of the students in control group and experimental group is used to find out the average of pretest score, the average of posttest score, and the average of $\mathrm{N}$-gain of both groups and the result is presented in Figure 1. Based on Figure 1, score improvement is shown in control group and experimental group. This score improvement yields medium $\mathrm{N}$-gain average for both groups. 


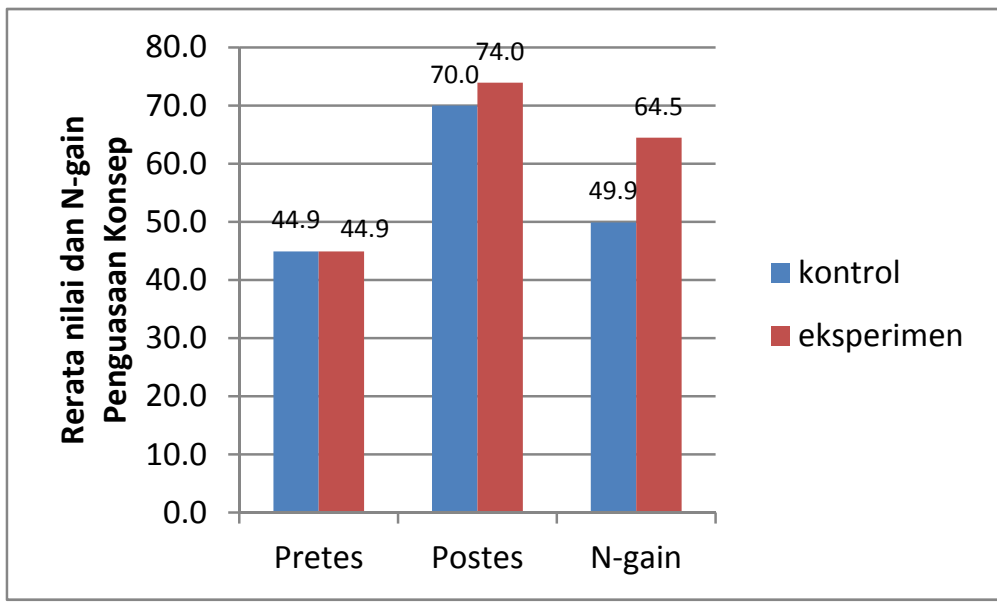

Figure 1: Histogram of pretest average, posttest average, and N-Gain of the students' concept mastery

Table 1 shows descriptive data analysis on the students' score for Science concepts mastery (score range 0 to 100). In the control group, science teaching yields posttest score average 67.46 for the concept of objects' shape characteristics and 72,53 for the concept that force can change object' shape and state of motion. The teaching of Science in the control group yields N-gain average in medium category, both for the concept of objects' shape characteristics and concept that force can change object' shape and state of motion. Thoroughly, Science concepts mastery of the students in the control group yields 70.03 posttest average score with SD 10.97 and N-gain average $34.91 \%$.

Table 1: Score Average, Standard Deviation, and N-Gain are normalized of Science of thorough Science concepts of control group and experimental group

\begin{tabular}{|c|c|c|c|c|c|c|c|c|c|c|}
\hline \multirow{3}{*}{$\begin{array}{l}\text { Concept } \\
\text { Mastery }\end{array}$} & \multicolumn{5}{|c|}{ Control Group } & \multicolumn{5}{|c|}{ Experimental Group } \\
\hline & \multicolumn{2}{|c|}{ Pretest } & \multicolumn{2}{|c|}{ Posttest } & \multirow{2}{*}{$\begin{array}{l}<\mathrm{g}> \\
\% \\
\end{array}$} & \multicolumn{2}{|c|}{ Pretest } & \multicolumn{2}{|c|}{ Posttest } & \multirow{2}{*}{$\begin{array}{l}<\mathrm{g}> \\
\% \\
\end{array}$} \\
\hline & Average & SD & Average & SD & & Average & SD & Average & SD & \\
\hline $\begin{array}{l}\text { Object's shape } \\
\text { characteristics }\end{array}$ & 54,05 & 15,57 & 67,46 & 12,97 & 32,60 & 34,42 & 12,82 & 70,16 & 13,15 & 59,48 \\
\hline $\begin{array}{l}\text { Force } \\
\text { influence on } \\
\text { objects }\end{array}$ & 59,60 & 18,04 & 72,53 & 12,76 & 33,78 & 39,82 & 19,00 & 77,67 & 10,94 & 65,59 \\
\hline Total & 56,86 & 15,10 & 70,03 & 10,97 & 34,91 & 37,15 & 10,78 & 73,96 & 10,15 & 64,50 \\
\hline
\end{tabular}

The teaching of Science in the experimental group yields posttest average 70.16 for the concept of object's shape characteristic and 77.67 for the concept of force influence on object's shape and state of motion. The teaching of Science for the experiment group yields $\mathrm{N}$-gain average in medium category. Although both control group and experimental group yields $\mathrm{N}$-gain average in medium category, if it is observed more carefully, $\mathrm{N}$-gain average of the control group is in lower medium group, whereas the one of the experimental group is in upper medium. Overall, the Science concept mastery of the experiment group yields posttest score average 73.96 with SD 10.15 and N-gain average $64.50 \%$. 


\section{Macrothink}

International Journal of Education

ISSN 1948-5476

2013, Vol. 5, No. 4

Table 2 presents N-gain distribution of students' concept mastery based on low, middle, and upper category of the control group and experimental group. In order to describe the distribution of the three categories, an analysis on the percentage of the students who get concept mastery $\mathrm{N}$-gain score average in each category.

Table 2: N-Gain Distribution for Concept Mastery Ability

\begin{tabular}{lcccccc}
\hline \multicolumn{1}{c}{ Concept } & \multicolumn{3}{c}{$\begin{array}{c}\text { Student Percentage on N-gain Category } \\
\text { Control }\end{array}$} & \multicolumn{4}{c}{ Experimental } \\
& High & Medium & Low & High & Medium & Low \\
\hline $\begin{array}{l}\text { Object shape } \\
\text { characteristics }\end{array}$ & 3,86 & 49,79 & 46,35 & 34,58 & 60,42 & 5 \\
$\begin{array}{l}\text { Force Influence towards } \\
\text { Object }\end{array}$ & 0,43 & 60,52 & 39,06 & 43,33 & 56,25 & 0,42 \\
\multicolumn{1}{c}{ Total } & 1,72 & 61,80 & 36,80 & 36,67 & 62,92 & 0,42 \\
\hline
\end{tabular}

In the control group, less than 5\% students get high category both for each concept and for thorough. In the experimental group, more than 30\% students get high category both for each concept and for thorough. Whereas, the number of students who are in low category in the experimental group is less than $5 \%$.

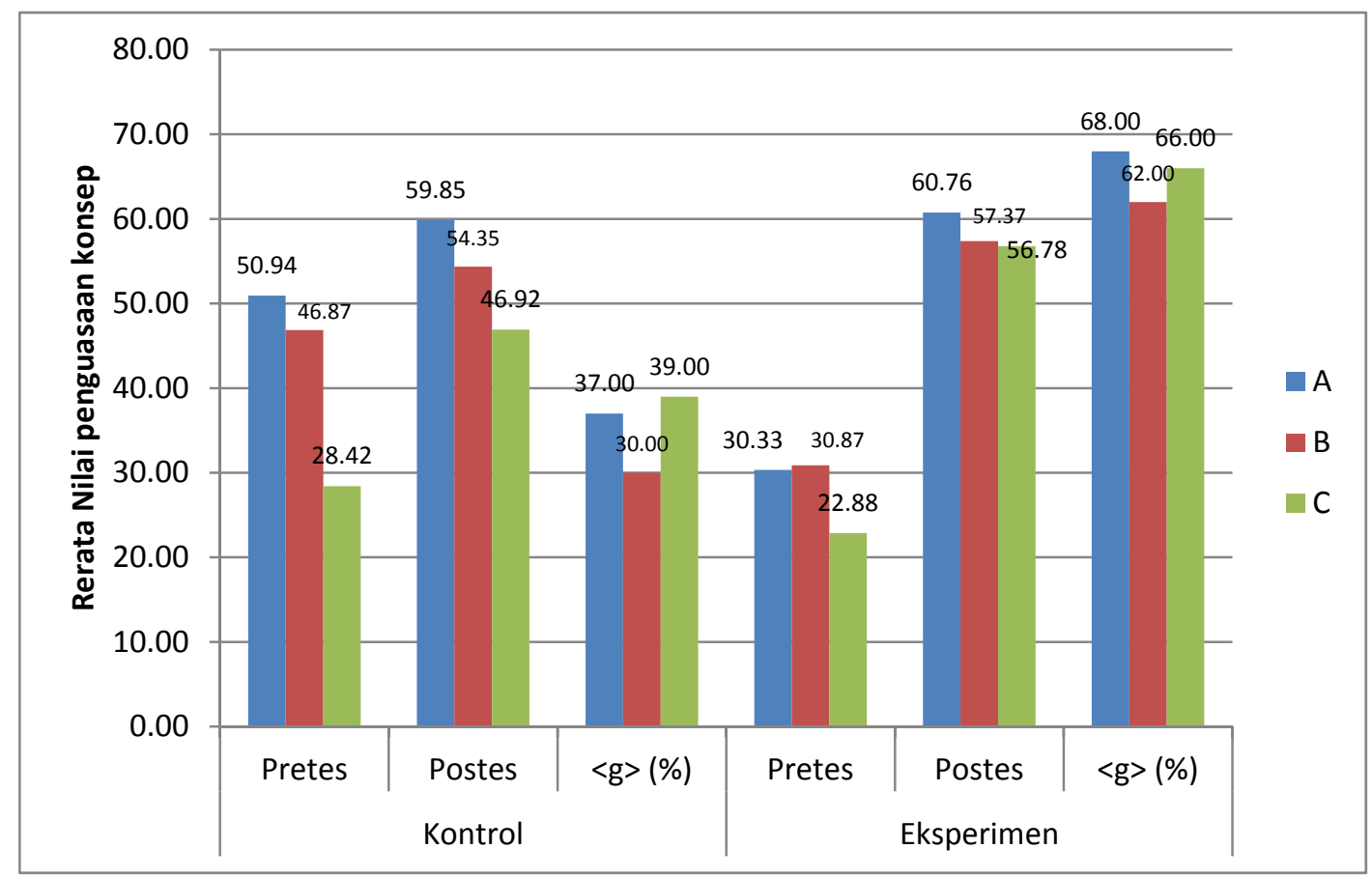

Figure 2: Histogram of Student Concept Mastery based on School Accreditation Status

Figure 2 shows the result of the student's science concept mastery based on the accreditation status of the control group and the experiment group. Figure 2 shows that the student's science concept score increases both for students of the schools with A, B, and C accreditation status both in control group and experimental group. The highest average is obtained by the students of the schools with A accreditation status, both in control group and 
experimental group. The increase of the score yields $\mathrm{N}$-gain average medium category in both groups. If it is reviewed carefully, although both are in medium category, but N-gain average in the control group tends to be in lower medium category and the experimental group is in upper medium category.

Figure 3 shows that student concept mastery is seen from student learning mastery. Based on Figure 3, students' percentage number increases to reach mastery learning both in control group and experimental group.

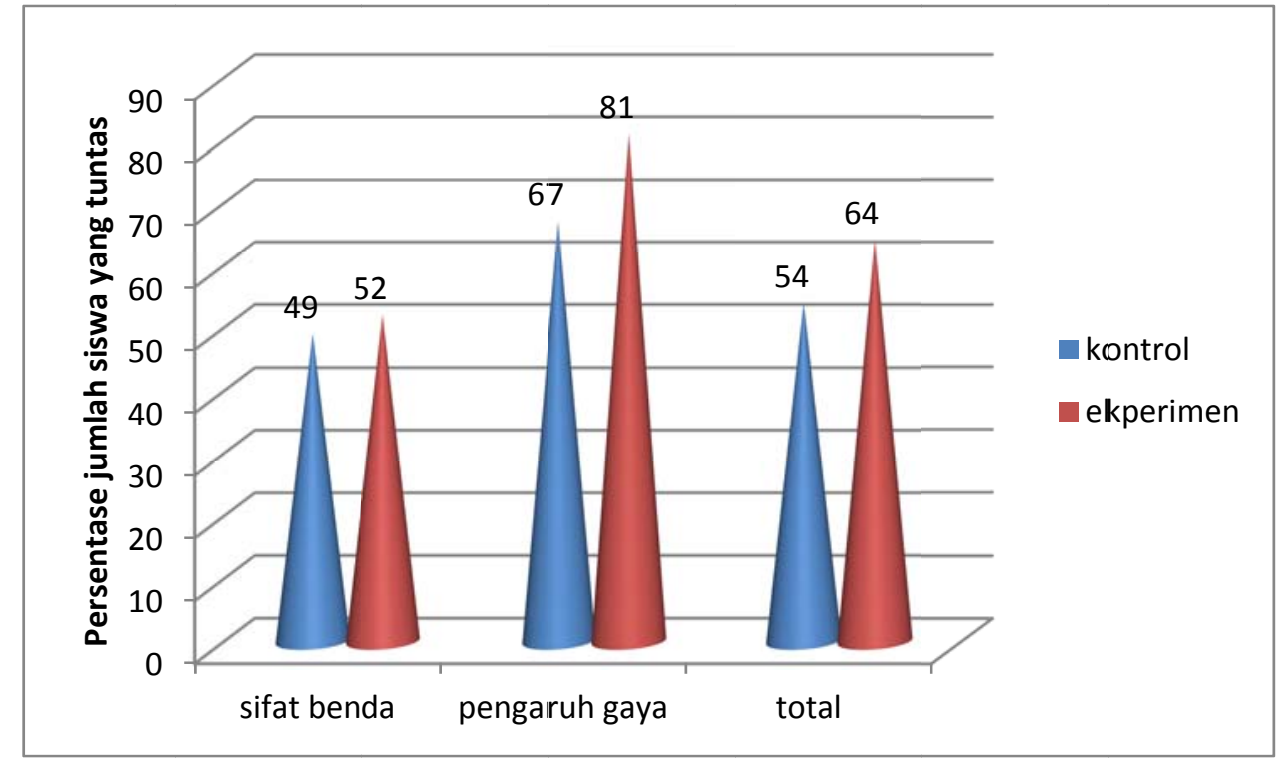

Figure 3: The Percentage of Science Concept Learning Mastery in Control group and Experimental Group

In order to find out whether the concept mastery $\mathrm{N}$-gain of the control group is different from experimental group, a test on the difference is carried out using inferential statistics i.e. ANOVA, with a requirement that the data must be in normal distribution and homogeneous. Normality test is done to show that the sample data is from a population with normal distribution. Homogeneity test is done to show that there are two or more sample data groups are from a population which has equal variance. Normality assumption test is carried out by using Kolmogorov-smirnov test. The tested hypothesis statements are as follow:

$\mathrm{H}_{0}$ : The sample is from a population with normal distribution.

$\mathrm{H}_{\mathrm{A}}$ : The sample is not from a population with normal distribution.

Significance rate $(\alpha)$ which is set for this research is 0.05. By the help of SPSS v.13.0, the criteria for $\mathrm{H}_{0}$ denial in this research is if the significance of differences is less than 0.05 . Table 3 shows the print-out result of the normality assumption test of concept mastery data and decision making data with some adjustments on the fonts of the letter and column. 
Table 3: The Normality Assumption Test of the Data of Concept Mastery and Decision Making Skill

\begin{tabular}{llccc}
\hline & & group & \multicolumn{3}{c}{ Kolmogorov-Smirnov(a) } \\
\hline \multirow{3}{*}{ concept } & & Statistic & df & Sig. \\
& experiment &, 044 & 240 &, $200\left(^{*}\right)$ \\
& control &, 042 & 233 &, $200\left(^{*}\right)$ \\
\hline
\end{tabular}

Based on table 3, it is obvious that the significance of differences for concept mastery and decision making skill both in control group and experimental group is more than 0.05 . This result shows that $\mathrm{H}_{0}$ which states that sample comes from population with normal distribution is accepted. Therefore, it can be inferred that the sample data comes from population with normal distribution, significance rate 0.05 .

Homogeneity test is done by using variance test. The hypothesis statements which will be tested are:

$$
\begin{aligned}
& \mathrm{H}_{0} \text { : The variance in each group is equal. } \\
& \mathrm{H}_{\mathrm{A}} \text { : The variance in each group is not equal. }
\end{aligned}
$$

The significance rate $(\alpha)$ which is set for this research is 0.05 . By the help of SPSS v.13.0, the criteria for $\mathrm{H}_{0}$ denial in this research is if the significance of differences is less than 0.05 . Table 4 shows the print-out result of the homogeneity assumption test of concept mastery data and decision making skill data with some adjustments on the fonts of the letter and column.

Table 4: The Homogeneity Assumption Test of Concept Mastery Data and Decision Making Skill Data

\begin{tabular}{llcccc}
\hline & & Levene & & & \\
& & Statistic & df1 & df2 & Sig. \\
\hline consept & Based on Mean &, 000 & 1 & 471 &, 982 \\
& Based on Median &, 000 & 1 & 471 &, 990 \\
& Based on Median and with adjusted df &, 000 & 1 & 462,417 &, 990 \\
& Based on trimmed mean &, 002 & 1 & 471 &, 965 \\
\hline
\end{tabular}

Table 4 shows the test with Based on Mean statistics for decision making skill yields significance 0.999 and concept mastery 0.982 which are both more than 0.05 . This result shows that $\mathrm{H}_{0}$ is accepted. Hence, it can be inferred that the research data is homogeneous.

Based on statistics assumption test above, the data has fulfilled the analysis requirements i.e. normality and homogeneity so that research hypothesis test with double ANOVA can be carried out. Double Classification Variance Analysis test (double ANOVA) is used to find out if there are differences in the concept mastery $\mathrm{N}$-gain of the control group and the experiment group, as well as considering the influence of school accreditation factor interaction. The hypothesis statements which will be tested are: 
$\mathrm{H}_{01}: \mu_{1}=\mu_{2}$ there is no significant difference on $\mathrm{N}$-gain average of the concept mastery score of the control group and the experimental group.

$\mathrm{H}_{\mathrm{A} 1}: \mu_{1} \neq \mu_{2} \quad$ there is significant difference on $\mathrm{N}$-gain average of the concept mastery score of the control group and the experimental group.

$\mathrm{H}_{02}: \mu_{1}=\mu_{2}$ there is no significant difference on $\mathrm{N}$-gain average of the concept mastery score of students from schools with accreditation status A, B, and $\mathrm{C}$.

$\mathrm{H}_{\mathrm{A} 2}: \mu_{1} \neq \mu_{2} \quad$ there is significant difference on $\mathrm{N}$-gain average of the concept mastery score of students from schools with accreditation status A, B, and C.

$\mathrm{H}_{03}: \mu_{1}=\mu_{2} \quad$ there is no significant interaction between the group type and school accreditation towards $\mathrm{N}$-gain average of the concept mastery score

$\mathrm{H}_{\mathrm{A} 3}: \mu_{1} \neq \mu_{2}$ there is significant interaction between the group type and school accreditation towards $\mathrm{N}$-gain average of the concept mastery score.

The significance rate $(\alpha)$ which is set for this research is 0.05 . With that significance rate, the

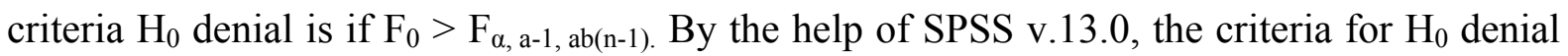
in this research is if the significance of differences is less than 0.05 .

Table 5: Results of Test of Average Thorough Concept Mastery N-gain Differences based on Group Type, Accreditation Status, and Interaction between group type and Accreditation Status

\begin{tabular}{llrrrrrr}
\hline \multirow{2}{*}{ Source } & \multicolumn{2}{c}{$\begin{array}{c}\text { Type III Sum } \\
\text { of Squares }\end{array}$} & df & $\begin{array}{c}\text { Mean } \\
\text { Square }\end{array}$ & F & Sig. & remark \\
\hline Accred & Hypothesis &, 477 & 2 &, 238 & 9,374 &, 096 No differences \\
& Error &, 051 & 2 &, $025(\mathrm{a})$ & & & \\
Group & Hypothesis & 9,023 & 1 & 9,023 & 360,039 &, 001 & There are differences \\
& Error &, 057 & 2,276 &, $025(\mathrm{~b})$ & & & \\
accred * group & Hypothesis &, 051 & 2 &, 025 & 1,234 &, 292 & No interaction \\
& Error & 9,623 & 467 &, $021(\mathrm{c})$ & & & \\
\hline
\end{tabular}

Table 5 shows the print-out result of the test of thorough concept mastery N-gain difference with some adjustments on the fonts of the letter and column. Based on table 5, it is obvious that science concept mastery thoroughly viewed from the group type has significance of differences less than 0.001 which is less than 0.05 . It shows that hypothesis that there is significant difference on $\mathrm{N}$-gain average of the concept mastery score of the control group and the experimental group is accepted. It is clear that the concept mastery $\mathrm{N}$-gain average as it is shown in table 1 for experiment group (i.e. 64.50) is bigger than the $\mathrm{N}$-gain of the control group (i.e. 34.91). The difference of the concept mastery is one of the factors because of the difference of the teaching models applied in the class, in which Multy-Cycle DEAL Teaching Model is better than the model which is previously used. 
The first stage of Multy-Cycle DEAL Teaching Model is Discussion. In this stage, students discuss the problems which are going to be solved. Discussion enables the students to exchange information, and it expands the information they already have in mind. It in line with Vygotksy (Slavin, 2000) that higher mental function appears in conversation or mutual cooperation between individuals before the higher mental function absorbed by the individuals. The second stage of Multy-Cycle DEAL Teaching Model is Exploration. The exploration stage is used to gather information which support the problems for instance by doing experiments or observation, reading books, article in newspaper, and other sources in internet. By doing these activities, it is expected that the students able to find information for themselves. It meets Bruner's statement that human being learns by active direct interaction with its surroundings, changes do not happen only in the environment, but also in the learning individuals themselves (Slavin, 2000). Furthermore, Piaget states that cognitive structure is formed while students interact with their surroundings (Dahar, 1996). Through active involvement in obtaining their knowledge, students will have the information will be last long in their mind, and it will be easily recalled at anytime. With this last long information, it is expected that the student's learning result will be better. The third stage is Analysis, that is doing an analysis on all gathered information by carefully check the information whether it is relevant or not with the problems. It is in line with Betch (in Santrock, 2008: 362) that in selecting information, it better to sort relevant and irrelevant information to reduce confirmation bias. Look-back is the last stage in Multy-Cycle DEAL Teaching Model, i.e. choosing the correct answer between the temporary answers which have been done in the beginning of the lesson by using the data from exploration activities, analysis, and conclusion.

Based on Table 5, the result of the test of concept mastery $\mathrm{N}$-gain average difference which is viewed from school accreditation status, it turns out that the significance of differences is 0.096 which is more than 0.05 . It shows that $\mathrm{H}_{0}$ which states that there is no significant difference on the concept mastery $\mathrm{N}$-gain score average of students from schools with accreditation status $\mathrm{A}, \mathrm{B}$, and $\mathrm{C}$ is accepted. In other words, the concept mastery $\mathrm{N}$-gain score average of students from schools with accreditation status $\mathrm{A}, \mathrm{B}$, and $\mathrm{C}$ is not different significantly.

Based on the interaction between group type and accreditation status, table 5 shows the significance of differences 0.292 which is more than 0.05 . It shows that $\mathrm{H}_{0}$ which states that there is no interaction between the group type and school accreditation towards the concept mastery is accepted. In other words, the influence of group type towards the N-gain average of student concept mastery score does not depend on school accreditation status.

Based on the result of this research, it is obvious that accreditation is not the main indicator of the school's teaching and learning quality. However, accreditation indirectly influences the quality of the teaching and learning management as it is showed by students' learning result. It means that school accreditation will indirectly control the teaching and learning quality. This finding supports the use of accreditation as an effort to assure and control school quality (BANS/M, 2009). 
When a school gets good accreditation rank, it directly indicates that the indicators in the accreditation instruments are good as well. The implication for the teaching and learning process is that schools with good accreditation will conduct their teaching and learning process appropriately, in which in their teaching and learning process they train their students to have high thinking ability. Besides, schools with high accreditation rank indicates that they are more open to innovation and give freedom to their stake holders to develop suitable with the world development. Such openness and freedom to innovate will also leads their students to develop their thinking ability.

\section{Closing}

Based on the findings and the discussion, it can be concluded that:

a. The science concepts mastery of the students who are taught with Multy-Cycle DEAL Teaching Model is in medium category with $\mathrm{N}$-gain average $64.50 \%$ and posttest average $73.96 \%$ with standard deviation 10.15 .

b. The concept mastery of the students who are taught with Multy-Cycle DEAL Teaching Model is different from those who are taught with the method which is previously used. The concept mastery of the students who are taught with Multy-Cycle DEAL Teaching Model is higher than that of the students who are with the method which is previously used.

c. Different accreditation status of the students does not cause different concept mastery.

d. There is no interaction between the kinds of the teaching model and school accreditation status towards science concept mastery.

Based on the research conclusion, as empirical implication, it is suggested that:

a. It is important to apply Multy-Cycle DEAL Teaching Model in teaching science in elementary school.

b. It is necessary to conduct replication research on the teaching of science in elementary school using Multy-Cycle DEAL Teaching Model which is conducted in longer time, using broader material coverage, and more research subjects. 


\section{References}

BANS/M. (2009). Kebijakan dan Pedoman Akreditasi Sekolah/Madrasah. Jakarta: Depdiknas.

Campbell, Vincent., Lofstrom, Jocelyn., \& Jerome, Brian. (1997). Decisions Based on Science. Arlington VA: National Science Teachers Association.

Dahar, R. W. (1996). Teori-Teori Belajar. Jakarta: Erlangga.

Fraenkel, Jack R., \& Wallen, Norman, E. (2003). How to Design and Evaluate Research in Education. Book 1. Boston: McGraw Hill.

Fraenkel, Jack R., \& Wallen, Norman, E. (2003). How to Design and Evaluate Research in Education. Book 2. Boston: McGraw Hill.

Permendiknas Nomor 16 Tahun 2007 tentang Standar Kualifikasi Akademik dan Kompetensi Guru.

Sadia. (1996). Pengembangan Model Belajar Kontruktivisme dalam Pembelajaran IPA di SMP (Studi Eksperimentasi dalam Pembelajaran Konsep Energi)

Santrock, John W. (2008). Psikologi Pendidikan. Jakarta: Prenata Media Group.

Slavin, Robert E. (2000). Educational Psychology Theory and Practice. Sixth Edition. Boston: Allyn and Bacon Publisher. . (1994). Educational Psychology: Theories and Practice. Fourth Edition.

Massachusetts: Allyn and Bacon Publishers.

Suryanti. (2012). Profil Kemampuan Berpikir Pengambilan Keputusan Berdasarkan IPA Siswa SD. Prosiding Seminar Nasional Sains 2012 Re-Orientasi Pembelajaran Sains ISBN 978-979-028-534-7. Surabaya: Unesa University Press.

\section{Copyright Disclaimer}

Copyright reserved by the author(s).

This article is an open-access article distributed under the terms and conditions of the Creative Commons Attribution license (http://creativecommons.org/licenses/by/3.0/). 